DOI 10.22460/infinity.v5i2.216

\title{
ANALYSIS OF STUDENTS MATHEMATICAL REPRESENTATION AND CONNECTION ON ANALYTICAL GEOMETRY SUBJECT
}

\author{
Muchamad Subali Noto ${ }^{1}$, Wahyu Hartono², Mohammad Dadan Sundawan ${ }^{3}$ \\ 1,2,3 Department of Mathematics Education, Swadaya Gunung Djati University, Cirebon Indonesia \\ ${ }^{1}$ balimath61@gmail.com
}

Received: May 20, 2016; Accepted: August 10, 2016

\begin{abstract}
The importance ability of mathematical representation and connection to owned by the student really help students in understanding the mathematical concepts in the form of pictures, symbols, and the written word. The use of mathematical representation and the correct connection by students will help students make mathematical ideas more concrete and can connect a concept to another concept, so that students can develop a view of mathematics as a whole integration. This research aims to describe and analyze the ability of representation and mathematical connection on the topics of analytical geometry. The research method was descriptive with the subject as much as 22 mathematics students. Data collected through tests and interviews. The results show that the average ability of representation is 46.00; the average mathematical connection ability is 36.77 . This means both the abilities still belongs to low, particularly for the ability of mathematical connection.
\end{abstract}

Keywords: Mathematical Representation, Mathematical Connection, and Analytical Geometry

\begin{abstract}
Abstrak
Pentingnya kemampuan representasi dan koneksi matematis untuk dimiliki oleh mahasiswa sangat membantu mahasiswa dalam memahami konsep matematis berupa gambar, simbol, dan kata-kata tertulis. Penggunaan representasi dan koneksi matematis yang benar oleh mahasiswa akan membantu mahasiswa menjadikan gagasan-gagasan matematis lebih konkrit dan dapat menghubungkan suatu konsep ke konsep yang lain, sehingga mahasiswa dapat mengembangkan pandangan matematika sebagai integrasi yang utuh. Penelitian ini bertujuan untuk mendeskripsikan dan menganalisis kemampuan representasi dan koneksi matematis mahasiswa calon guru matematika pada matei geometri analitik. Metode penelitian adalah penelitian deskriptif dengan subjek mahasiswa calon guru matematika sebanyak 22 mahasiswa. Teknik pengumpulan data menggunakan tes dan wawancara. Hasil menunjukkan bahwa rata-rata kemampuan representasi sebesar 46,00; rata-rata kemampuan koneksi matematis sebesar 36,77. Ini berarti kedua kemampuan tersebut masih tergolong rendah, terutama untuk kemampuan koneksi matematis.
\end{abstract}

Kata Kunci: Representasi Matematis, Koneksi matematis, dan Geometri Analitik

How to Cite: Noto, M.S., Hartono, W. \& Sundawan, M.D. (2016). Analysis of Students Mathematical Representation and Connection on Analytical Geometry Subject. Infinity, 5 (2), 99-108 


\section{INTRODUCTION}

A Committee on Undergraduate mathematics or CUPM recommends that each program should include activities that help students in developing analytical thinking, critical reasoning, problem solving, communication skills and acquire the habit of thinking mathematically. Those activities should be designed to promote and measure progress of students in learning mathematics, one of them with communicating mathematical ideas clearly and coherence through writing and speaking.

Student understanding of the mathematical concepts, and the ability of students in using mathematical ideas can be seen from how students choose the right way in representing its mathematical ideas. NCTM (2000) states that when students have access to mathematical representation and ideas that they show, then they have a bunch of tools that will significantly expand their capacities in thinking mathematically.

As expressed by Jones (2000), there is a need for some reason the ability of representation, namely: is the ability to build basic concepts and mathematical thinking, and to have a good understanding of the concepts that can be used in problem solving. Wahyudin (2008) also added that representation could help the students to organize his thoughts.

Learning by emphasizing mathematical representation is a demanding mental activity learning students optimally in understanding a concept. Bruner (Hasanah, 2004) said that to understand the most important mathematical concepts is not storage of past experience but how to get back the knowledge that has been stored in memory and are relevant to the needs and can be used when needed.

The importance of the ability of mathematical representation for the owned by the student really help students in understanding the mathematical concepts in the form of pictures, symbols, and the written word. The use of the right of representation by students will help students make mathematical ideas more concrete. A complex problem would be much simpler if you use a representation that corresponds to a given problem, otherwise false representation of construction make the problem difficult to be solved.

With regard to the theory of Bruner, according to Ruseffendi (2006), in mathematical learning needs to pay attention to the four propositions, namely; drafting (construction), the notation, contrast and diversity (variation), and connectivity. The evidence for the preparation explaining that in studying mathematics, it will be more embedded if student conduct themselves the order of representation. The evidence for notation explained that in the learning needs to consider the use of a notation which corresponds to the mental development of the child. The evidence for contrast and diversity explaining that in order to make the concept becomes more meaningful, it should be a contrasting concept dishes and diverse. While the evidence for connectivity explains that the learning process needs to consider the opportunity of studying the relation between concepts, topics, and between branches of mathematics.

The ability to connect between the concepts, topics and between branches of mathematics called mathematical connection abilities. According to Fisher, Daniels, \& Anghileri (Suhendar, 2007) making connection is a way to create understanding and instead understand something means making a connection. To understand an object in depth one must know: (1) the object itself; (2) his relations with other similar objects; (3) the relationship with other 
similar objects; (4) the dual relation with other objects of its kind; and (5) relationship with other objects in the theory (Suhendar, 2007).

The mathematical connection means the activities connect between mathematical concepts; connect mathematical concepts with the concept of other lessons; apply thought and modeling mathematics to solve the problems that appear in other disciplines such as art, music, psychology, science and business; even also is the activities connect the concept of mathematics with the daily life. NCTM popularising the mathematical connection in his native language of English called mathematical connection and make it as one of the six curriculum standards.

In addition, students who have the ability of a good connection will be easier to learn the multitude of learning materials with how to connect the material to one another. NCTM (2000) justify the statement and proposed that without the mathematical connection ability, students must learn and remember many concepts. Continued NCTM (2000), when the students are able to connect a concept to other concepts, then they have developed views of mathematics as a whole integration. This means that the purpose of the mathematical connection is intended to broaden the students, see mathematics as a unified whole not stand alone and know the relationship and the benefits of mathematics both in school and outside the school.

The geometry is a mathematics lesson materials that need a good mathematical ability to understand it. According to NCTM (Siregar, 2009: 5) abilities that must be owned by the student in learning geometry is: 1) the ability to analyze the characters and the nature of the geometry either two dimensional or three dimensional, and able to build these arguments regarding the relationship mathematics geometry with the other; 2) the ability to determine the position of a point with more specific and image spatial relationship with using the coordinates geometry and connect it with the other system; 3) application abilities transformation and its use in the symmetric to analyze mathematical situation; 4) is able to use visualization, spatial reasoning, and model geometry to solve problems. By mastering the abilities, students are expected to master the material in the geometry with better.

Sunardi (2007) stated that in comparison with other math materials, the geometry of the position of the most concern. The difficulty of college students in learning geometry occurs starting from Elementary School to College (PT). If studied more about the link between geometry objects that abstract with the difficulty students in learning geometry, then it would appear that there are indeed problems in learning geometry in school are associated with the formation of abstract concepts. Learn the abstract cannot be done only with the transfer of information, but it takes a process of formation of concepts through a series of activities that is experienced directly by the student. The series of activities of formation of abstract concepts that hereafter the process of abstraction.

Nurhasanah (2010) states that fit the characteristics of geometry, abstraction processes must be integrated with the process of learning that goes so should pay attention to some aspects like, learning methods, models of learning, learning materials, availability and use of props or teacher skills in managing learning activities.

One of the branches of the geometry is analytic geometry. This courses are intended to give an understanding to the students about the basic concept in the analytically geometry so that the students can solve the problems related to the concepts in analytically geometry. The 
courses of analytic geometry also has an important role in providing a strong foundation for students to learn more advanced courses such as Transformation Geometry, Calculus II, Advance Calculus I and II. This courses presents many visual representation such as a picture or graph, representation symbols as the common denominators of mathematics and demanding the student to explain it verbally/orally.

Based on these problems, this article will discuss the related to the ability of mathematical representations and connection students of analytical geometry with the formulation of the problem as follows.

1. How the mathematical representation ability of mathematics students?

2. How the mathematical connection ability of mathematics students?

\section{METHOD}

This research is a descriptive research, with the aim to describe and analyze the ability of mathematical representation and connection students based on the data obtained. Description of the method is selected for researchers attempting to uncover the factual situation regarding the ability of mathematical representation and representation students. Research subject as much as 22 students of mathematics from Unswagati that contracted courses Analytical Geometry. Data collection method in the form of a test and an interview. Research instruments include test of mathematical representation and connection, and interview sheet.

\section{RESULTS AND DISCUSSION}

Based on the mathematical representation of ability, obtained the following results. Table 1 shows the results of a mathematical representation ability (MRA).

Table 1. Statistics KRM

\begin{tabular}{lll}
\hline $\mathrm{N}$ & Valid & 22 \\
& Missing & 0 \\
Mean & & 46,0000 \\
Median & 46,0000 \\
Mode & 10,00 \\
\hline
\end{tabular}

Based on Table 1 of the output above, seen that the results of the average (mean) and median are the same value. Average MRA reach 46.00. This shows the average MRA are not optimal, because it is still under 50. It means to MRA remains to be improved again. Seen from the mode value of 10.00 . These values are still below average, it means the MRA Unswagati student tend to the left. Median value $=46.00$, meaning that there is a 50\% (100 students) get value under 46.00. This indicates that the MRA is still low or less than optimal, it also reinforced with a value of mode which is still below average. 
Table 2. Max and Min MRA Value

\begin{tabular}{lll}
\hline $\mathrm{N}$ & Valid & 22 \\
\multicolumn{1}{c}{ Missing } & 0 \\
Std. Deviation & & 24,82510 \\
Variance & & 616,286 \\
Minimum & & 9,00 \\
Maximum & & 95,00 \\
Percentiles & 15 & 11,3500 \\
& 25 & 27,2500 \\
& 50 & 46,0000 \\
& 75 & 65,0000 \\
\hline
\end{tabular}

Based on the Table 2, obtained that the standard deviation 24,82 . This means that the spread of the MRA data is 24,82 from the average. Minimum value $=9$ and maximum value 95.00, this means that there is a student with low and the highest MRA. There are 25\% (22 students) that MRA is under 27.25 and $15 \%$ is under 33.33. In the percentiles 75 , the value of MRA is 65 , it means that 25 percent students get MRA value above the average.

Based on its achievements of each mathematical representation indicator, presented in Table 3 below.

Table 3. Achievements of MRA

\begin{tabular}{|c|c|c|c|c|}
\hline No. & Measured Indicator & $\begin{array}{c}\text { Average } \\
\text { Score }\end{array}$ & $\begin{array}{l}\text { Max. } \\
\text { Scor } \\
\text { e }\end{array}$ & $\begin{array}{c}\text { Achieveme } \\
\text { nts } \\
(\%)\end{array}$ \\
\hline \multicolumn{5}{|c|}{$\begin{array}{l}\text { R1. Presents the mathematical problems in the } \\
\text { visual model. }\end{array}$} \\
\hline 1. & $\begin{array}{l}\text { Drawing straight lines forming a } \\
\text { specific angle with another straight } \\
\text { line. }\end{array}$ & 5 & 10 & 50 \\
\hline 5. & $\begin{array}{l}\text { Drawing a circle with the center of } \\
\text { the known and alluded to a straight } \\
\text { line. }\end{array}$ & 4,82 & 10 & 48,2 \\
\hline \multicolumn{5}{|c|}{$\begin{array}{l}\text { R2. Identify and use the object, process and } \\
\text { procedures that are appropriate in various } \\
\text { representation. }\end{array}$} \\
\hline 3 & $\begin{array}{l}\text { Determine the equation of a } \\
\text { tangent on circles if known } \\
\text { gradient. }\end{array}$ & 2,59 & 10 & 25,9 \\
\hline 4. & $\begin{array}{l}\text { Identify the center, radius and the } \\
\text { equation of a circle through three } \\
\text { points. }\end{array}$ & 19,59 & 40 & 48,98 \\
\hline
\end{tabular}




\begin{tabular}{|c|c|c|c|c|}
\hline No. & Measured Indicator & $\begin{array}{l}\text { Average } \\
\text { Score }\end{array}$ & $\begin{array}{c}\text { Max. } \\
\text { Scor } \\
\text { e }\end{array}$ & $\begin{array}{c}\text { Achieveme } \\
\text { nts } \\
(\%)\end{array}$ \\
\hline \multicolumn{5}{|c|}{$\begin{array}{l}\text { R3. Linking the procedures and processes in } \\
\text { various representations in relevant concept. }\end{array}$} \\
\hline 2 & $\begin{array}{l}\text { Determine the area of the image of } \\
\text { the triangle through the long sides. }\end{array}$ & 8,64 & 20 & 43,2 \\
\hline
\end{tabular}

Table 3 above shows that the indicator R1-R3 measured with questions no 1-5 obtained its achievements by $50 \% ; 43.2 \% ; 25.9 \% ; 48,98 \% ; 48,2 \%$. This shows that overall the indicator the average has not yet reached $75 \%$.

The first indicator is measured with questions no. 1 and 5, presented the problems related to the straight line and the circle, students complete the problem with are modeling visually to describe the straight line and the circle. There are 25 percent of the total amount of students are modeling problems visually correctly, the remaining $75 \%$ mistaken in applying the concept to resolve the issue so the model that made it wrong.

The second indicator is measured with questions no. 3 and 4, identify and use the object, process and procedures that are appropriate in a representation of the circle equation. $10 \%$ of students can identify and use the three coordinates of the point that passed by the circle, to apply the procedure of elimination or substitution the linier equation to get the circle equation, $80 \%$ mistaken in the concept of the count and one procedure of elimination or substitution.

The third indicator is measured with questions no. 2, linking the procedures and processes in various representations relevant concept. $36 \%$ of students can linking procedures and the process of searching for broad and provide an explanation in writing related to the two straight lines that are perpendicular to each other on a visual representation in the form of a picture triangle. $36 \%$ of students can linking with appropriate procedures and processes, $64 \%$ mistaken in the concept and count.

Based on the mathematical connection ability data obtained the following result. Table 4 shows the results of the students mathematical connection ability (MCA).

Table 4. Statistics MCA

\begin{tabular}{lcc}
\hline $\mathrm{N}$ & Valid & 22 \\
& Missing & 0 \\
Mean & & 36,7727 \\
Median & & 30,5000 \\
Mode & & 25,00 \\
\hline
\end{tabular}

Based on the Table 4 in the above output, seen that the results of the average (mean) and median almost the same value. The average MCA reach 36,00. This shows the average MRA is not optimal, because the value is below 50. That means the MCA also still must be improved again. The mode is 25.00, below the average, that means MRA Unswagati Students tend to the left. The median value $=30.00$, that means $50 \%$ (100 students) get under 36.00 
value. This shows that the MCA still low or less than optimal, is also strengthened by mode value that is still below the average.

Table 5. Max and Min Value of MCA

\begin{tabular}{lcc}
\hline $\mathrm{N}$ & Valid & 22 \\
\multicolumn{1}{c}{ Missing } & 0 \\
Std. Deviation & & 25,4893 \\
& & 7 \\
Variance & & 649,708 \\
Minimum & & 6,00 \\
Maximum & & 81,00 \\
Percentiles & 15 & 7,4500 \\
& 25 & 10,5000 \\
& 50 & 30,5000 \\
& 75 & 62,5000 \\
\hline
\end{tabular}

Based on the Table 5, obtained that the standard deviation 25,48. This means that the spread of MCA data is approximately 25,48 from the average. Minimum value $=6$ and maximum value 81,00, this means that there is a student with low MCA and the highest MRA of 81 . There are around 25\% (22 students) that MRA under 10,50 and 15\% under 7.45. There is also 25 percent students get MCA value above the average.

Based on its achievements of each mathematical connection indicator, presented in Table 6 below.

Table 6. Achievements of MCA

\begin{tabular}{|c|c|c|c|}
\hline Measured Indicator & $\begin{array}{l}\text { Average } \\
\text { Score }\end{array}$ & $\begin{array}{l}\text { Max. } \\
\text { Score }\end{array}$ & $\begin{array}{l}\text { Achieveme } \\
\text { nts } \\
(\%)\end{array}$ \\
\hline \multicolumn{4}{|l|}{$\begin{array}{l}\text { K1. Looking for relations of } \\
\text { various representations of the } \\
\text { concept. }\end{array}$} \\
\hline $\begin{array}{l}\text { 6. Explain the relationship } \\
\text { between the two straight } \\
\text { line based on the image. }\end{array}$ & 5,62 & 10 & 56,2 \\
\hline \multicolumn{4}{|l|}{$\begin{array}{l}\text { K2. Apply math in other fields } \\
\text { or in everyday life. }\end{array}$} \\
\hline $\begin{array}{l}\text { 7. Apply the concept of an } \\
\text { elliptical surface in the } \\
\text { field of health }\end{array}$ & 1,72 & 10 & 17,20 \\
\hline $\begin{array}{l}\text { 8. Apply the concept of an } \\
\text { elliptical surface in the the } \\
\text { bridge construction }\end{array}$ & 1,90 & 10 & 19,00 \\
\hline
\end{tabular}




\begin{tabular}{llccc}
\hline No. Measured Indicator & $\begin{array}{c}\text { Average } \\
\text { Score }\end{array}$ & $\begin{array}{c}\text { Max. } \\
\text { Score }\end{array}$ & $\begin{array}{c}\text { Achieveme } \\
\text { nts } \\
(\mathbf{\%})\end{array}$ \\
\hline $\begin{array}{l}\text { Apply the concept of a } \\
\text { circle related to the } \\
\text { problem of radar }\end{array}$ & 7,45 & 15 & 49,70 \\
& & & \\
\hline
\end{tabular}

Table 6 above shows that the indicator K1 and K2 measured with questions no.6-9 obtained its achievements of $56.2 \% ; 17.2 \% ; 19 \% ; 49,70 \%$. This shows that overall the indicator the average has not yet reached $75 \%$.

The indicator K1 measured with questions no.6, presented the problems related to the straight line, students explain the relationship between the representation visually, that explain the relationship between the two straight line based on the image of the given triangle. There are 40 percent of the total amount of students can give an explanation about the relationship between the two straight lines is analytically correctly, the remaining $60 \%$ mistaken in applying the concept and create a symbol.

The indicator K2 measured with questions no. 7-9, apply mathematics in other areas or in everyday life. $22,7 \%$ students can apply the concept of an elliptical surface in the field of health or related to the bridge construction, $77.3 \%$ mistaken in the concept and count. 36,36\% students can apply the concept of a circle related to the problem of radar, 63,64,3\% mistaken in the concept and count.

\section{CONCLUSION}

The ability of mathematical representation students on the material of analytical geometry especially related to the system of the coordinates kartesius, straight line, circle and ellipse still low. They are not able to apply the concepts, error in performing operations, cannot visuallize (drawing a straight line or circle) and cannot use the procedures related to the specific representation. Mathematical connection ability of the mathematics students also still low. They are not able to understand the problem, cannot apply the concepts in everyday life, error in performing operations and cannot create a symbol properly.

After knowing the mathematical abilities, the authors give suggestions for the next researcher: 1) implementing a learning geometry software-assisted model related in mathematical representation and connection ability, the purpose using this software is to assist students in visualizing geometric objects, so that it can build an internal representation of the students. 2) designing teaching materials with the activities of mathematical representations and connection on the analytical geometry. The development of teaching materials must be based to the description of the abilities of the attention to the difficulty/confusion created by the students. 


\section{REFERENCES}

Committee on the Undergraduate Program in Mathematics. (2004). Undergraduate Programs and Courses in the Mathematical Sciences: CUPM Curriculum Guide 2004. http://www.maa.org/cupm/summary.pdf.

Coxford, A.F. (1995). The Case for Representation.Dalam P.A. House dan A.F Coxford (Eds). Yearbook Connecting Mathematics Across The Curriculum. Reston, VA: The National Council of Teachers of Mathematics.

Hasanah,A. (2004). Mengembangkan Kemampuan Pemahaman Matematika Siswa SMP melalui Pembelajaran Berbasis Masalah yang Menekankan Pada Representasi Matematika.Tesis PPs UPI. Bandung: Tidak Diterbitkan.

Hudojo, H. (2002). Representasi Belajar Berbasis Masalah.JournalMatematika atau Pembelajarannya. ISSN:085-7792. Tahun VIII, Edisi Khusus.

Hwang,W. Y., Chen, N. S., Dung, J. J., \& Yang, Y. L. (2007). Multiple Representation Skill and Creativity Effects on Mathematical Problem Solving using a Multimedia Whiteboard System.Educational Technology and Society. Vol 10 No. 2: 191-212.

Jones, B.F., \& Knuth, R.A. (1991). What does research about mathematics?[Online]. Tersedia: http://www. ncrl.org/sdrs/areas/stw_esys/2math.html.

Jones, A.D. (2000). The Fifth Process Standard: An Argument To Include Representation In Standar $2000 . \quad$ [Online]. http://www.math.umd.edu/ dac/650/jonespaper.html.

Kaput, J. J dan Goldin, G. A. (2004).A Join Perspective on the Idea of Representation in Learning and Doing Mathematics.[Online]. Tersedia: http://www.simmalac.usmassad.edu.

NCTM (2000).Principles and Standards for School Mathematics. Reston: Virginia.

Nurhasanah, F. (2010).Abstraksi Siswa SMP dalam Belajar Geometri melalui Penerapan Model Van Hiele dan Geometer's Sketchpad (Junior High School Students' Abstraction in Learning Geometry Through Van Hiele's Model and Geometer's Sketchpad). Tesis SPS UPI Bandung: Tidak Diterbitkan.

Ruseffendi, E.T. (2006). Pengantar kepada Membantu Guru Mengembangkan Kompetensinya dalam Pengajaran Matematika untuk Meningkatkan CBSA. Bandung: Tarsito.

Siregar, N. (2009). Studi Perbandingan Kemampuan Penalaran Matematik Siswa Madrasah Tsanawiyah Kelas yangbelajar geometri Berbantuan Geometer's Sketchpad dengan Siswa yang Belajar tanpa Geometer's Sketchpad. Tesis SPs UPI Bandung: Tidak Diterbitkan. 
108 Noto, Hartono \& Sundawan, Analysis of Students Mathematical Representation ...

Suhendar (2007). Meningkatkan Kemampuan Komunikasi dan Koneksi Matematika Siswa SMP yang Berkemampuan Rendah Melalui Pendekatan Konstektual dengan Pemberian Tugas Tambahan. Tesis pada SPs UPI: Tidak diterbitkan.

Sumarmo, U. (2010). Berfikir dan Disposisi: Apa, Mengapa dan Bagaimana Dikembangkan pada Peserta Didik. FPMIPA UPI.: Tidak Diterbitkan.

Sunardi.(2007). Hubungan Tingkat Penalaran Formal dan Tingkat Perkembangan Konsep Geometri Siswa. Jurnal Ilmu Pendidikan. Jakarta: LPTK dan ISPI.

Wahyudin. (2008). Pembelajaran dan Model-Model Pembelajaran. Bandung: UPI. 